\title{
Multilingual-sensitive professional action competence and pre-service teachers' beliefs - a happy marriage?
}

\author{
Niesen Heike \\ Goethe University Frankfurt/Main, Germany; Niesen@em.uni-frankfurt.de
}

\begin{abstract}
The present study addresses a major concern in current German pre-service EFL teacher education: The development of prospective teachers' multilingual-sensitive professional action competence that is their ability to make use of their future pupils' multilingual resources to enhance EFL teaching and learning processes with a lexical focus. To this end, two identical teacher training classes held at Goethe University Frankfurt/Main, Germany are presented, the primary aims of which were to raise students' awareness of multilingual-sensitive teaching approaches on the one, and to enable them to design multilingual-sensitive EFL lessons with a lexical focus on the other hand. Given insights from earlier research, namely that teachers' beliefs and (prior) experiences "interact differently with the theoretical knowledge they gain in lectures" (Ellis 2006: 7), and to gain holistic insights into the development of participants' competence, their beliefs about quality criteria of EFL teaching and learning processes with a lexical focus as well as the sources of these beliefs were addressed in classes. Not surprisingly, results show that students' beliefs at the onset of classes were firmly rooted in their personal Language Learning Biographies and heavily shaped by mono-, rather than multilingual teaching and learning approaches. However, it could also be shown that students' beliefs changed throughout the training, a finding which bears important implications for future teacher training classes.
\end{abstract}

Keywords: multilingualism, teacher beliefs, Language Learning Biography

\section{Introduction}

In the course of the "Multilingual Turn" (May 2014), widely accepted assumptions about language teaching and learning have been challenged, amongst them the overarching conviction that language teaching and learning should be strictly monolingual endeavors (Cenoz \& Gorter 2011). As such, the respective target language is to be used "exclusively" (Cummins 2007) in the language classroom for languages should be kept rigidly separate (Cook 2009), especially since it is widely believed that the inclusion of languages other than the target language hinders rather than supports the language learning process and will ultimately prevent language learners from achieving near-native speaker competence (Ortega 2014). Numerous calls to reject these notions in favor of an understanding of language learning and teaching as a process which should account for the linguistic heterogeneity language learners represent in language classrooms around the globe have been made (Conteh \& Meier 2014, García \& Wei 2014, Otwinowska \& De Angelis 2014, Vetter \& Jessner 2019). These calls are grounded on research findings which show that multilingual language learners possess language learning potentials monolingual learners tend to have less command of (Franceschini 2011). These potentials, or "funds of knowledge" (González, Moll \& Amanti 2005) include a heightened level of metalinguistic ability (Bialystok 2001), language awareness (Jessner 2006), and language learning strategies (Otwinowska 2016), to name but a few.

Interestingly, the teaching and learning of the English language has been ascribed an important role in unfolding these potentials, despite the fact that English is still connected to "linguistic imperialism" and even seen as a "killer language" which spreads at the expense of other languages (House 2003: 556, 574). Contrary to this view, the function of English as a "bridge language" which lends itself well to language transfer (Reissner 2019), an important tenet of multilingual approaches to language teaching and learning, is increasingly gaining acceptance, especially (though not exclusively) in German educational contexts, where linguistic heterogeneity in language teaching and learning classes has become the norm rather than the exception. Hence, the question as to how pupils' linguistic resources 
may be used to enhance EFL learning has gained momentum. Pupils' linguistic resources in this context are manifold: Some bring first languages other than the target language English and the official language German to class, often on various levels of competence (Elsner 2015) These pupils, who often share a migration background, are frequently still in the process of learning German as their second language on a BICS and CALP level (Cummins 2008) when entering the EFL classroom. It is not uncommon for them to use home languages such as Turkish or Arabic, and to employ German or a mix of languages when talking to their peers. As a result, it is common for them to switch between languages to adjust to specific communicative needs (Hu 2003). Pupils who have been raised rather monolingually (here: German), extend their multilingualism in more formal ways, that is during their school career, within which languages such as French, Spanish or Italian are learned besides English. Thus, pupils' linguistics resources are heterogeneous in themselves since they are shaped by the context within which pupils have learned or are learning languages, the respective age when learning started as well as the competence levels they have in these languages, which is subject to continuous change rather than stable (Butler 2013, Herdina \& Jessner 2002). Given this, it is obvious that the assumption that all pupils in an EFL learning group share the same monolingual (German) linguistic background is clearly outdated. However, this assumption, also known as the "monolingual habitus" (Gogolin 2008) is still prevalent in many German EFL classes and leads teachers to stick to teaching approaches which emerge from this habitus: Pupils' linguistic resources are excluded from the classroom rather than included, teaching and learning processes are characterized by a target-language-only-approach.

This approach is persistent despite numerous calls for more multilingual-sensitive language teaching and learning, both from an educational policy (Council of Europe 2001) as well as from a research stance. As for the latter, findings show that the inclusion of learners' language resources such as their first languages can enhance their target language competence (Göbel et al. 2010, Bündgens-Kosten et al. 2016). In language classrooms, however, multilingual-sensitive foreign language teaching in the above sense is still rarely found, a circumstance that is understandable from teachers' perspectives for many feel ill-prepared to engage in multilingual-sensitive ways of teaching (Bredthauer \& Engfer 2016). Hence, it seems reasonable to strongly argue for multilingual-sensitive EFL teaching to be an integral part of preservice teacher education and in-service teacher professional development (Göbel et al. 2010), a demand which is, however, not sufficiently responded to (De Angelis 2011).

The following contribution attempts to address this gap: Two identical pre-service EFL teacher classes held in the winter term of 2017/18 at Goethe University Frankfurt/Main, Germany are presented, the primary aims of which were to raise students' awareness of multilingual-sensitive teaching approaches and to enable them to design multilingual-sensitive EFL lessons with a lexical focus. Both classes were part of the project LEVEL ("Linking Pedagogic Expertise through Video-Enhanced Learning Scenarios") which is funded by the Federal Ministry of Education and Research in the course of the "Campaign for the Quality of Teacher Education" program of the German federal and state governments.

The relevance of these classes' results from the meaningfulness multilingual-sensitive teaching approaches have for future EFL teachers (for the reasons outlined above). The didactic conception of the classes owes to the nature of multilingual-sensitivity: Although it mirrors current linguistic changes in German EFL classrooms in terms of pupils' linguistic heterogeneity, as well as the didactic demands which go along with these changes, it has not established itself in EFL classes yet (Cutrim Schmid \& Schmidt 2017, Jakisch 2014). It is still more of a didactic innovation which are, in turn, known for rarely being implemented into practical teaching processes as long as they do not correspond to teachers' subjective theories (beliefs) about teaching and learning (Reusser \& Pauli 2014). Hence, pre-service teachers' beliefs were explicitly addressed in the two classes portrayed here. In what follows, a theoretical rationale on multilingual-sensitive professional action as well as on teachers' beliefs is offered. Next, the methodological approach of the study at hand is elaborated on, followed by its results which illuminate the following research questions: Which beliefs concerning quality criteria of EFL 
teaching and learning with a lexical focus do students express at the beginning of the classes? Where do these beliefs stem from? Do students' beliefs change throughout the classes?

A section on how findings may inform future teacher training classes to develop prospective EFL teachers' multilingual-sensitive professional action competence rounds off the contribution.

\section{Theoretical background I: multilingual-sensitive professional action competence}

The concept of multilingual-sensitive professional action competence (henceforth, multilingual action competence) has been theoretically derived from Shulman's "subject matter knowledge for teaching" (Shulman 1986), Weinert's "action competence" (Weinert 2001) and Baumert and Kunter's notion of "knowledge-in-action" (Baumert \& Kunter 2006) in a prior investigation on the development of preservice teachers' multilingual action competence (Niesen 2018b). I have already argued in this prior study for the necessity to elaborate on what multilingual action competence entails, especially because existing models and conceptions of teachers' action competence are largely rooted in general pedagogical aspects, whereas domain-specific conceptions of teachers' action competence are still rare, not to speak of conceptions which address even further specifications such as, in this case, multilingual action competence (Niesen forthcoming). The working definition of teachers' multilingual action competence which has been suggested reads as follows: It is "the didactic ability to examine various options for action with regard to learners' language learning prerequisites and to relate these options to intended learning objectives (Niesen 2018b: 123; trans.). In this definition, language learning prerequisites cover linguistic resources pupils bring to the EFL classroom such as (first) languages they already know, the strategies they have applied when consciously learning further languages in different contexts (before English), as well as the way they employ their languages to meet various communicative needs in and outside the classroom.

For it has become widely acknowledged that pupils' linguistic resources do not unfold their potential for further language learning automatically, it is up to teachers to make pupils aware of the linguistic resources they have at their command, and to create learning scenarios which enable pupils to actively draw on these resources. A number of suggestions of what these scenarios might look like have been put forward. They include creating a language-friendly environment within which pupils' languages other than English are valued (Elsner 2015), initiating explicit language comparisons on morphological, lexical and syntactic levels to have pupils uncover similarities and differences between languages and, ultimately, to strengthen the cognitive dimension of their language awareness (Schnuch 2015), engaging in inter- as well as intralingual prospective and retrospective language transfer, and transfer of language learning strategies (Meißner 2004), and encouraging pupils to employ their first language(s) as a "base of reference" when learning English (Butzkamm 2003). Further options include providing pupils opportunities to negotiate language meaning, form and subject content in "multilingual discourse" (Cenoz \& Gorter 2015), especially to avoid simplifications (Gibbons 2006) which might occur due to the fact that pupils' linguistic abilities in the target language often have not (yet) developed to such an extent as to allow for discussions about complex topics and phenomena, as well as more practical things such as having pupils' who share similar language backgrounds but are heterogeneous in terms of their target language competence (Schmelter 2005) work together in groups. Needless to say that teaching and learning scenarios like this put high demands on both, teachers and learners alike, especially since they are frequently accompanied by teacher and learner roles which differ to a considerable extent from their traditional conception: If a multilingual approach to EFL teaching and learning is taken seriously, it is the pupils, not the teachers who act as "language experts" (at least in those phases where their L1s are explicitly included). It is the teachers' responsibility to bundle multilingual contributions in a way as to make them fruitful springboards for the enhancement of pupils' target language competence that is the intended learning objectives in the definition of multilingual action competence above. I have termed the attempt to foster learners' target language competence through multilingual teaching as the 
"multilingualism-as-tool" approach (Niesen 2019: 139) to stress the functional purpose of multilingual teaching.

The final component in the above definition of multilingual action competence which demands for clarification is pre-service EFL teachers' ability to examine various options for action in terms of their multilingual-sensitivity. These options refer to teachers' decisions as to how to structure a lesson, his or her didactic approaches as well as choice of methods to be used in a lesson. Whereas in previous studies on pre-service EFL teachers' professional development, these options were either elicited from case vignettes provided by the teacher educator (myself), or as ready-made descriptions of teaching scenarios to choose from, in the present study the options for action had to be developed by pre-service teachers themselves by designing lesson plans. At this point, it might be argued that the mere design of a lesson plan cannot be equated with actually acting out this plan in real classrooms. However, the design of a lesson plan certainly is a part of professional action competence when perceived as "reflection-foraction", the purpose of which is to "guide future [teacher] action" and is therefore "proactive in nature" (Farrell 2007: 6). Further, pre-service teachers were also engaged in "reflection-on-action" which is "retroactive" for it "involves thinking back on what was done" (Farrell 2007: 5, see also Tsui 2012).

It has already been mentioned in the introductory section that didactic innovations such as multilingual sensitivity in EFL classrooms need to take into account teachers' beliefs about language teaching and learning if they are to be implemented in schools and unfold their potential to enhance pupils' language learning. Kubanyiova and Feryok have made this connection even more explicit, stating that "the relevance of the field [language teacher cognition] needs to happen through linking teacher cognition to meaningful teacher development and students' learning, and that it needs to occur in response to changing linguistic, cultural, and socioeconomic realities of language classrooms around the world" (ibid. 2015: 437). Promising research findings which show that teachers' cognitions cannot only be linked to "changing linguistic realities", but that these beliefs can be shaped so as to include positive attitudes towards multilingual teaching and learning (Dooly 2005) encourage the study at hand.

\section{Theoretical background II: teacher cognition}

When in the early 1970 s educational researchers began to change research perspectives from teacher behavior to the underlying cognitions which drive this behavior, scientific interest increasingly focused on teacher beliefs about teaching and learning (Borg 2006). As early as in the 1960s behavioristicoriented educational research was criticized for not taking into account teachers' mental structures and their influence on both, teacher professional behavior and student learning (Ashton 2015). In the decades to follow, research into teachers' cognitions gained importance and went through several developments which cluster around four perspectives which have become known as the "individualist ontology", the "social ontology", the "sociohistorical ontology" as well as the "chaotic systems ontology" (Burns, Freeman \& Edwards 2015). A brief account of these phases shall be presented here.

Conceptual and empirical approaches to illuminate teachers' cognitions which were (and are) shaped by an "individualist ontology" view teachers' cognitions as "reified mental constructs, that is, static and discrete entities that are typically dissociated from action and context, as well as other dimensions of teachers' inner lives (e.g., emotions, motivations, values). Teachers' cognitions are assumed to be acquired as a result of their professional and personal experiences, readily accessed and articulated in self-reports, and applied (or not) in teaching practices. It is also assumed that a match between stated beliefs and practices is desirable" (Kubanyiova \& Feryok 2015: 437).

As Burns et al. (2015) show, research from this cognitive perspective has put forward important insights, amongst them the finding that cognitions involve "complex conceptual processes", that "the interrelationships between cognition and practice were not necessarily consistent or convergent", and that the view of cognitions as stable entities which could be "mediated over time through professional development and educational experiences" is to be challenged (ibid.: 589f). Given this, the pave was 
grounded for a more social perspective on the perception of and research on teacher cognition, in the course of which contextual factors, "both internal to the person and external in the social setting" (Burns et al. 2015: 591) which shape teacher cognitions became of interest. To illuminate the complex interplay of contexts, teacher learning and teacher cognition, teachers themselves were to elaborate on their beliefs about teaching, often through diary studies (Burns et al. 2015). In this vein, teachers also "reflected on their own language learning experiences and either accepted or rejected techniques they had been exposed to" (Burns et al. 2015: 592). Research conducted primarily from a "sociohistorical ontology" brought to light teacher cognitions which operated amongst a group of teachers as "shared principles" (Burns et al. 2015: 593), as agreed-upon norms about teaching and learning which have been mentioned in later contexts as "shared beliefs" (Oser \& Blömeke 2012: 417), or as established norms embedded in a specific societal context which determines beliefs about functions of and behavior within a specific school system (Tschannen-Moran et al. 2017).

One of the most recent developments in teacher cognition research adopts a perspective which offers "fresh lenses through which to view the interrelationships among beliefs, knowledge and practice" (Burns et al. 2015: 593). A prominent study conducted from this stance has revealed important insights into how teacher learning in a professional development course unfolded (Kiss 2012). The author argues for an understanding of teacher learning as being a "complex system" characterized by "sensitivity to initial condition, unpredictability, having a nested structure showing a non-hierarchic network system and feedback loops" (Kiss 2012: 30). Further, teachers' cognitions clustered around four identities, namely "self as a learner, self as a teacher, self as an administrator, and personal self" (Kiss 2012: 22), all of which tend to be linked to teachers' past, present and future experiences and conceptions. Kiss found that what teachers learned in the course and how they learned it was to a considerable extent influenced by the fact that they jumped back and forth between their identities and that learning, as a result, appears to be "non-linear" and "highly unpredictable" (Kiss 2012: 17). The author concludes that "participants used an elaborate network of links to events, people or places in their past, present, and future in order to create a personal understanding and meaning of the topics discussed during the course. The findings clearly indicate that participants were selective in what they considered important to mention in their reflective journals, although they were exposed to the same educational experience" (Kiss 2012: 17).

This is not to say that teacher education does not have an impact on teacher thinking, which it clearly does, it rather implies that teacher education should be sensitive to the nature of teachers' different learning processes and especially their pre-existing conceptions of teaching when entering teacher training courses. The role teachers' pre-existing beliefs about language teaching and learning, the roots of which go back to Lorties' (1975) concept of "apprenticeship of observation", has been acknowledged by numerous researchers such as Johnson (2015) who emphasizes that "[t]eacher learning neither begins nor ends within a teacher education program. In fact, the duration of the typical teacher education program, whether pre-service or in-service, pales in comparison to teachers' schooling histories, life experiences, and the accumulation of teaching experience" (ibid.: 525), or Freeman (2002) who argues that "[f]rom a teacher-education standpoint therefore, the teacher learners' contexts of mind provide a meeting point between prior knowledge, as life history, background, social position, experience and so on, and the present experience and interaction of the teacher education activity or course" (ibid.: 10). As for the lack of time in teacher professional development programs mentioned by Johnson (2015), it has been shown that especially formats within which teachers reflect on their beliefs while, at the same time, generate new knowledge about teaching and learning have proven to be effective (Parkinson \& Maggioni 2017). In the same line, Reusser and Pauli (2014) emphasize that a lack of "subject knowledge" may seriously hinder the development and change of beliefs, which is why they argue for "situated, problem- and action-oriented professional development formats which include the implementation of teaching videos" (ibid.: 655; trans.). This way, they say, teachers can be offered alternative ways of 
classroom action which, in turn, enables their altered beliefs to enter the level of classroom behavior which would otherwise remain on a purely cognitive level (ibid.: 645; trans.).

The influential power pre-existing teachers' beliefs exercise on teacher learning has also been stressed by Kubanyiova (2012) who suggests an "integrative model of Language Teacher Conceptual Change" which covers "some of the "prototypical reactions that teachers have when they are introduced to new ideas or reform initiatives" (ibid.: 61): Whether teachers' beliefs change or not throughout educational programs is subject not only to the input provided in these programs, but also to various steps teachers undertake when confronted with new input, that is they "evaluate it quickly through the filter of their existing cognitions", they check whether the input "propels the teacher to experience a discrepancy between her perceived actual and ideal or ought-to self", followed by several "threat appraisal[s]" during which teachers estimate, for example, whether the respective input is practicable in their specific teaching contexts (ibid.: 60f.). The "discrepancy" the author refers to is mirrored by the notion of a "disequilibrium" (Parkinson \& Maggioni 2017: 228) which incorporates challenges which create an imbalance of teachers' existing competencies, beliefs and (new) tasks to be performed and which triggers teachers to leave their "epistemological comfort zone" (Schraw et al. 2017a: 16). In sum, Kubanyiova (2012) underlines that "teacher developmental programs or processes do not cause change, but that we need to talk instead of multiple reasons for change or lack thereof and, equally, multiple routes of development" because "[t]eacher conceptual development does not follow a predictable trajectory" (ibid.: 191). The complex interplay of teachers' beliefs and teachers' professional development is also highlighted by Fives \& Buehl (2017) who state that teachers' beliefs serve a threefold function, namely as "filters", "frames" and "guides": As "filters" beliefs can influence the intake and interpretation of new information. As "frames" they may influence the approach chosen to perform specific tasks. This is where specific beliefs are consciously activated: "Although we consider framing to be an active process that the individual is aware of, the degree of awareness may vary from a highly intentional activation of particular beliefs to a more habitual or automatic activation of beliefs for framing a task" (ibid.: 38). Beliefs which function as "guides" not only leave their imprint on teachers' observable decisions, but also on perceptions about future professional behavior (Fives \& Buehl 2017).

A useful theoretical conception of teacher cognition development has been put forward by Parkinson \& Maggioni (2017) and their "epistemic developmental path" (ibid.: 218). The developmental continuum inherent in this "path" ranges from naïve and rather dualistic to highly complex, more sophisticated beliefs (Schraw et al. 2017b). The specific levels of development are accompanied by teachers' preferences as to how teaching and learning processes should be designed: "The realist worldview assumes that there is an objective body of knowledge that is best acquired through experts via transmission [...]. Teachers with a realist worldview teach actively to students who are viewed as passive recipients of a pre-established knowledge base, downplaying the role of peers. [...]. The contextualist worldview assumes that learners construct shared understanding in contexts in which teachers serve as facilitators. The relativist worldview assumes that each learner constructs a unique knowledge base that is different but equal to that of other learners. [...]. Their main goal is to promote student self-regulation, which enables students to learn autonomously in the future" (ibid.: 332).

It is obvious that multilingual teaching, and the development of multilingual action competence among (pre-service) EFL teachers demands for a "contextualist worldview", given that pupils are to play an active role in sharing their knowledge of languages learned before English as well as accompanying learning strategies. The goal to enable pupils to "learn autonomously in the future" as represented in the "relativist worldview" is also inherent in multilingual teaching for it aims (at least in the long run) at putting pupils in the position to make informed decisions about when and how to activate their linguistic resources to enhance further (foreign) language learning. 


\section{Methodology}

Against the backdrop of the theoretical aspects and research findings outlined in the previous sections, the investigation addresses the following research questions:

1. Which beliefs concerning quality criteria of EFL teaching and learning (with a lexical focus) do students express at the beginning of the classes?

2. Where do these beliefs stem from?

3. Do students' beliefs change throughout the classes?

In what follows, the design and implementation of the classes investigated is elaborated on, followed by the exemplification of the methodological approach chosen.

Both classes ( $\mathrm{N}=23,18 \mathrm{f}, 5 \mathrm{~m}$ ) were held at Goethe University Frankfurt/Main, Germany, in the winter term of 2017/2018. Classes were open to advanced pre-service EFL teachers, all of whom had gained prior teaching experience either through a practical teaching semester at a local school or due to school internships accompanied by university classes. A total of nineteen students had additional experiences as substitute or assistant teachers. Participants studied to become teachers in various secondary school forms. As for participants' cultural and linguistic background, which has been elaborated on in detail in an earlier study (Niesen 2018c), it can be said that the entire group was heterogeneous for it included various first languages such as German, Korean, Russian, English, Urdu, Turkish, and Dutch besides numerous other languages which had been acquired or learned in and outside formal contexts. Classes ran for 15 weeks with one 90-minute session per week. Both classes covered the module "Innovations in language teaching" of the official study regulations at Goethe University.

Students' multilingual action competence was trained in a threefold manner: First, theoretical texts about multilingualism in EFL teaching and learning were discussed to raise students' awareness of the topic and to make them familiar with multilingual-sensitive teaching approaches. Second, EFL teaching videos were analyzed in terms of their multilingual-sensitivity. In this context, students were to elaborate on to what extent the videotaped teachers engaged in multilingual-sensitive teaching and whether the approach served to achieve target language learning objectives. Students were also suggested to design alternative teaching designs if they found the perceived one not appropriate. Two types of EFL teaching videos were used, namely simulated and authentic ones. The former were videotaped microteachings within which pre-service teachers who had participated in prior university classes conducted by the author of this article were given role cards and acted out as "teachers" and "pupils". In contrast, authentic videos were generated in real school contexts. Since both types of videos have their specific strengths and weaknesses when it comes to the development of pre-service teachers' professional competence (Niesen 2018a), a combination of both was chosen in the classes investigated here.

The entire training phase took 11 sessions and was framed by two sessions at the beginning and at the very ending of the classes to collect data to gain insights into the research questions. To answer the first and second research question, students filled out a questionnaire termed "My Language Learning Biography". Not only did it include information on the number of languages participants have command of, on their levels of competence in these languages as well as the age and context of learning, it also included an item which asked students to explicitly elaborate on their beliefs. More specifically, they were to write a short text on what they believe are essential quality criteria of EFL teaching and learning in general and with a lexical focus in particular. Students were free to exemplify their beliefs on EFL teaching and learning with beginner, intermediate, and more advanced pupils. They were further asked to indicate where they think their beliefs stem from. Students' texts were subject to qualitative content analyses (Kuckartz 2016), resulting in a category system which illustrates their beliefs at the beginning of classes. To gain further insights into students' beliefs at the beginning of the classes they were asked to design a lesson plan with a lexical focus. The plan clustered around the text "Visit Dartmoor National Park" taken from a textbook frequently used in German secondary school EFL classes (Biederstädt 2013). The text was chosen for it is frequently employed in real secondary EFL classrooms in numerous German 
federal states and therefore poses a challenge to be expected by future teachers. Instructions read as follows:

Instruction on "Visit Dartmoor" (VD I)

Pupils are introduced to the following new vocabulary: hang-gliding, mud running, climbing, fox, owl, badger, pony, river, tent, map, (...).

Imagine you were the EFL teacher of a 6th grade with about 30 pupils. With the help of the "Visit Dartmoor" introductory pages from the textbook design a mini lesson: Explain carefully and in detail which steps you take to achieve the lesson goals (pupils grasp the meaning of the new words and are able to use them in meaningful contexts). Give reasons for your decisions.

Background information about the EFL learning group included pupils' linguistic resources as well as their target language competence. Students prepared their lesson plans as a table (phase, content, learning goals, social form, media) and elaborated on it in a coherent written text. In a next step, participants were asked to write a short reflection on the question whether (and to what extent) their lesson plans mirror their beliefs about quality criteria of EFL teaching in general and with a lexical focus in particular. Hence, the instruments used to illuminate participants' beliefs about quality criteria of EFL teaching and learning (with a lexical focus) falls into three parts:

a) The questionnaire "My Language Learning Biography"

b) The design of "Visit Dartmoor" lessons (VDI)

c) The reflections on possible connections between a) and b)

The fact that students' were asked to express their beliefs in the questionnaire suggests that the study at hand falls under the individualist-cognitive ontology of research on teachers' cognitions as exemplified in the previous section. This is exactly why this instrument was accompanied by the lesson design instrument which allowed students to put their beliefs into practice, and, in turn, to enable the researcher to gain more implicit, that is, activity-based insights into students' beliefs. As Freeman (2002) put it quite convincingly: "We need to understand that articulation and reflection are reciprocal processes. One needs the words to talk about what one does, and in using those words one can see it more clearly. Articulation is not about words alone, however. Skills and activity likewise provide ways through which new teachers can articulate and enact their images of teaching" (ibid.: 11). It was assumed here that some of the beliefs mentioned in the questionnaires would find their precipitation in the lesson plans for it has been shown that "[c]onclusions about teacher beliefs can [...] be drawn from the analysis of teachers' lesson plans (Fives \& Buehl 2017). To find out whether and to what extent students' beliefs could be detected in the lesson plans, the category systems which represent students' beliefs were applied to the lesson plans in a deductive manner to identify beliefs therein. Before categories were applied, two cooperating experts were trained to do so (1.5 hours). Throughout the training, ambiguous categories were redesigned to avoid double coding. Subsequently, nearly $20 \%$ of the lesson plans were coded by the experts. The resulting percent agreement was $78 \%$, interrater reliability turned out to be substantial, $\mathrm{k}=0.76$.

The reflections were subject to discussion in class, taking account of the insight that "[w]hen teachers describe their [...] beliefs, they do not simply put words into pre-existing mental mechanisms that reside, fully developed and ready to be coherently articulated, in their heads. When they tell, they tell with a particular purpose, to a particular audience. What and how they tell is shaped by the context of the telling which influences what can, should, or even must be told about their selves" (Kubanyiova \& Feryok 2015: 438f.). The reflection process itself included what has become known as "reflexivity" (Brownlee \& Schraw 2017): "Whereas reflection involves the self (subject) thinking about some object, reflexivity involves critical thinking that goes beyond such reflection to evaluate teaching practice in the light of personal epistemologies" (ibid.: 412). Referring to Archer (2007), the authors continue: "The 
distinguishing feature of reflexivity is that it has the self-referential characteristics of 'bending-back' some thought upon self, such that it takes the form of subject-object-subject. This is likely to lead to reasoned action and epistemic growth for the individual" (ibid.: 412). Of course, there was no guarantee that participants actually engaged in these processes, which is another reason why the written reflections were discussed with peers and the supervisor, the latter of whom shaped the discussion so as to make "reflexivity" to occur more likely.

To answer the third research question, students were told to redesign their lesson plans on "Visit Dartmoor National Park" (VD I) in multilingual-sensitive ways (VD II). It was assumed that this task served as an "equilibrium" which provided a challenge for students for none of them had attended a course on multilingual teaching and learning with a specific focus on EFL lexis before (information gained in informal discourse with participants). Put differently, their "pre-understandings" were assumed to be "inadequate" to perform the task (Johnson 2015: 525f.). To promote the inclusion of the entirety of knowledge and skills gained throughout classes in the lesson plans, students were advised to revise their redesigned lesson plans in the last session and hand them in after classes had ended. Again, there was a reflection task which asked students to elaborate on possible connections between their redesigned lesson plans and their beliefs initially expressed in their Language Learning Biographies. Both classes were rounded off by a questionnaire within which students were to exemplify whether they think their initial beliefs had changed in the course of the classes and if so, to what extent and in what ways.

A word of caution is necessary at this point: Given insights from research on teachers' cognitions from a social and complex systems ontology, especially the finding that teachers' learning follows nonpredictable and winding paths, neither the redesigned "Visit Dartmoor" lessons (VD II) nor the accompanying reflection and final questionnaire can serve to "prove" that participants' beliefs had changed (or not), and that this change is due to the knowledge they gained throughout classes, first and foremost because it was found that "changes in trainees' behavior" are not necessarily "accompanied by changes in their belief system" (Kubanyiova 2012: 18). However, the combination of questionnaires and lesson plans corresponds to Kubanyiova's conviction that "our understanding of teacher change is limited if self-reported cognitions are examined in isolation of behaviors because behavioral change does not imply cognitive change and vice versa" (ibid.: 18).

\section{Results and discussion}

Table 1 illustrates students' initial beliefs about quality criteria of EFL teaching and learning in general. As can be seen from the number of sub-categories, beliefs belonging to the category "learnerorientation" (category 1) were quite differentiated. The importance students ascribe to this category is also reflected in the absolute numbers in the left column which show how many students opted for the relevant sub-category.

Almost half of the students are convinced that the target language English should be used in the EFL classroom (category 2), followed by skill-orientation (category 3 ) and a clear lesson structure (category 4).

Table 1: Category system "beliefs about quality criteria of EFL teaching and learning in general".

\begin{tabular}{|c|c|c|}
\hline Category & Definition & Example \\
\hline $\begin{array}{c}\text { 1. Student-orientation } \\
6(26.09 \%)^{*}\end{array}$ & $\begin{array}{c}\text { Statements which refer to ... } \\
\text { (no pupil-oriented choice of contents and methods } \\
\text { (not teacher-centered) }\end{array}$ & "Inclusion of pupils" \\
\hline $\begin{array}{c}1.1 \text { Variety of methods } \\
14(60.87 \%)\end{array}$ & $\begin{array}{c}\text {... the use of a variety of media (texts, films, etc.) and } \\
\text { social forms (SW, PW, GW, plenum)** to address } \\
\text { various senses and to adapt teaching to different }\end{array}$ & $\begin{array}{c}\text { "Teaching should include } \\
\text { many different methods" }\end{array}$ \\
\hline
\end{tabular}


ERL Journal Volume 2019-2(2). Enhancing Multiculturalism in EFL Communication

\begin{tabular}{|c|c|c|}
\hline & learner types & \\
\hline $\begin{array}{c}1.2 \text { Oral contributions } \\
9(39.13 \%)\end{array}$ & ... the promotion of all pupils' oral contributions & "Pupils should talk a lot" \\
\hline $\begin{array}{l}\text { 1.3 Differentiation } \\
8(34.78 \%)\end{array}$ & $\begin{array}{c}\text {... supporting "weak" and challenging "strong" } \\
\text { pupils. Here, individuals' target language } \\
\text { competencies are decisive }\end{array}$ & $\begin{array}{l}\text { "Consider pupils' different } \\
\text { levels of achievement" }\end{array}$ \\
\hline $\begin{array}{l}\text { 1.4 Dealing with } \\
\text { mistakes } \\
6(26.09 \%)\end{array}$ & $\begin{array}{l}\text {... the way pupils' mistakes are dealt with. Mistakes } \\
\text { should be considered as a part of the learning } \\
\text { process. Anxiety among pupils is to be avoided. }\end{array}$ & $\begin{array}{l}\text { "Constructive learning } \\
\text { atmosphere, pupils should } \\
\text { not be afraid of making } \\
\text { mistakes" }\end{array}$ \\
\hline $\begin{array}{l}1.5 \text { Level and } \\
\text { development of } \\
\text { learning achievements } \\
5(21.74 \%)\end{array}$ & $\begin{array}{l}\text {... the level and development of pupils' target } \\
\text { language learning achievements. These are to be } \\
\text { checked on a regular basis by the teacher (via tests, } \\
\text { discussion of pupils' task results, etc.). Feedback } \\
\text { about their personal level of competence is to be } \\
\text { provided to pupils }\end{array}$ & $\begin{array}{l}\text { "Continuous learning } \\
\text { progress", "Frequent tests" }\end{array}$ \\
\hline $\begin{array}{l}\text { 1.6 Pupils' living } \\
\text { conditions } \\
4(17.39 \%)\end{array}$ & $\begin{array}{l}\text {... the inclusion of pupils' living environments and } \\
\text { everyday routine outside school. This also means the } \\
\text { inclusion of pupils' personal interests }\end{array}$ & $\begin{array}{l}\text { "Teaching should refer to } \\
\text { pupils' living conditions" }\end{array}$ \\
\hline $\begin{array}{l}\text { 2. Use of the target } \\
\text { language } \\
\text { (and German if } \\
\text { necessary) } \\
10(43.48 \%)\end{array}$ & $\begin{array}{l}\text {... the exclusive, at least predominant use of the } \\
\text { target language in the classroom (by teachers and } \\
\text { pupils). German may be referred to if necessary }\end{array}$ & $\begin{array}{l}\text { "No other language than } \\
\text { English should be used" }\end{array}$ \\
\hline $\begin{array}{l}\text { 3. Competence/ } \\
\text { skill-orientation } \\
5(21.74 \%)\end{array}$ & $\begin{array}{l}\text {... the promotion of as many skills as possible } \\
\text { (reading, writing, listening, speaking)as well as of } \\
\text { mediation. There can, but does not have to, be a } \\
\text { focus on more than one skill simultaneously }\end{array}$ & $\begin{array}{l}\text { "A focus should be to } \\
\text { combine the } 4 \text { skills" }\end{array}$ \\
\hline $\begin{array}{l}\text { 4. Structure } \\
3(13.04 \%)\end{array}$ & $\begin{array}{c}\text {... clear planning and structure of teaching. This } \\
\text { covers dividing a lesson into identifiable phases and } \\
\text { transparent learning goals }\end{array}$ & $\begin{array}{l}\text { “...clear introduction: } \\
\text { Transparent presentation of } \\
\text { lesson procedure" }\end{array}$ \\
\hline
\end{tabular}

*Mentions in Language Learning Biographies (absolute numbers and percent); ${ }^{* *}$ Single-, partner-, groupwork

The following major quality criteria of EFL teaching and learning could be derived from students' remarks:

EFL teaching and learning should be characterized by a variety in methods in terms of social forms (plenum, single-, partner- and groupwork), media (texts, films, illustrations) and task types. The target language is to be used, if not exclusively, to the highest extent possible by teachers and learners. Teaching and learning is learner-oriented in such a way as teachers take pupils' pre-knowledge into account and adopt their teaching to learners' heterogeneous competence levels and learning types via differentiation. Further criteria cover the perception of mistakes as parts of the learning process as well as regular documentation and assessment of the learning progress including informative feedback, especially with regard to the "5 skills". Contents of teaching include pupils' personal interests, the structure of teaching and learning scenarios falls into clearly identifiable phases (introduction, working phase, conclusion). 
Students' beliefs about quality criteria of EFL teaching with a lexical focus are presented in Table 2 (as an extension of Table 1 categories are continuously numbered). Utmost importance was attached to teaching strategies which put vocabulary introduction and use into meaningful contexts, as well as to training the correct pronunciation of new words. Only three students explained that multilingualsensitive elements should play a role in EFL teaching with a lexical focus (category 9).

Table 2: Category system "beliefs about quality criteria of EFL teaching and learning with a lexical focus".

\begin{tabular}{|c|c|c|}
\hline Category & Definition & Example \\
\hline $\begin{array}{l}\text { 5.Contextualisation } \\
5(21.74 \%)\end{array}$ & $\begin{array}{c}\text { New words are learned in context, not as single, } \\
\text { isolated units }\end{array}$ & $\begin{array}{l}\text { "Pupils should learn new } \\
\text { words in context" }\end{array}$ \\
\hline $\begin{array}{l}5.1 \ldots \text { to present new } \\
\text { vocabulary } \\
8(34.78 \%)\end{array}$ & $\begin{array}{c}\text { New words are presented by the teacher in complex } \\
\text { meaningful contexts (coherent texts, videos etc.). } \\
\text { This can serve both, the explanation of word } \\
\text { meanings by the teacher as well as decoding word } \\
\text { meanings by pupils }\end{array}$ & $\begin{array}{l}\text { "The meanings of words } \\
\text { needs to be explained, e.g. by } \\
\text { telling pupils a story which } \\
\text { contains the words" }\end{array}$ \\
\hline $\begin{array}{l}5.2 \text {... to apply/use new } \\
\text { vocabulary } \\
11(47.83 \%)\end{array}$ & $\begin{array}{l}\text { New words are put into a meaningful context by } \\
\text { pupils (they write coherent texts which contain } \\
\text { these words) to consolidate pupils' word knowledge }\end{array}$ & $\begin{array}{l}\text { "To strengthen pupils' word } \\
\text { knowledge they should put } \\
\text { words in a meaningful context } \\
\text { by formulating their own } \\
\text { sentences" }\end{array}$ \\
\hline $\begin{array}{l}\text { 6. Pronunciation } \\
13(56.52 \%)\end{array}$ & $\begin{array}{l}\text { The correct pronunciation of new words is presented } \\
\text { by a model (teacher, CDs). Pronunciation is practiced } \\
\text { through continuously repeating new words (either a } \\
\text { single pupil or the entire class in choir) }\end{array}$ & $\begin{array}{l}\text { "Teacher should serve as a } \\
\text { model for correct } \\
\text { pronunciation, difficult words } \\
\text { are repeated by pupils" }\end{array}$ \\
\hline $\begin{array}{l}7 . \\
\text { Consideration/diagnosi } \\
\text { s or activation of prior } \\
\text { knowledge } \\
8(34.78 \%)\end{array}$ & $\begin{array}{c}\text { Pupils' pre-knowledge may cover linguistic } \\
\text { knowledge (words they already know) and real- } \\
\text { world knowledge (general knowledge). The inclusion } \\
\text { of this knowledge serves to reduce the cognitive } \\
\text { load pupils' face when learning new words. New } \\
\text { knowledge is to be integrated into knowledge which } \\
\text { already exists }\end{array}$ & $\begin{array}{l}\text { "Teachers should show pupils } \\
\text { the contrast between what } \\
\text { they already know and what } \\
\text { they do not yet know (in } \\
\text { terms of word knowledge)" }\end{array}$ \\
\hline $\begin{array}{l}\text { 8. Game-based } \\
\text { strategies } \\
8(34.78 \%)\end{array}$ & $\begin{array}{l}\text { The implementation of games (role plays, riddles } \\
\text { etc.) serves to enhance both, pupils' motivation and } \\
\text { their ability to memorize new words. Further, it } \\
\text { helps to train pronunciation and can be used for } \\
\text { diagnostic purposes }\end{array}$ & $\begin{array}{l}\text { "Test pupils' word knowledge } \\
\text { in a playful manner" }\end{array}$ \\
\hline $\begin{array}{l}\text { 9. Multilingualism } \\
\quad 3(13.04 \%)\end{array}$ & $\begin{array}{l}\text { Pupils' knowledge of languages other than the target } \\
\text { language English and the official language German is } \\
\text { actively used in teaching and learning vocabulary }\end{array}$ & $\begin{array}{l}\text { "Inclusion of pupils' first and } \\
\text { second languages" }\end{array}$ \\
\hline
\end{tabular}

As for the first research question, it is safe to say that students' beliefs about quality criteria of EFL teaching and learning (with a lexical focus) at the onset of the classes clustered around the principles of learner-oriented, communicative EFL teaching and learning scenarios, the structure and implementation of which lies almost exclusively in the teacher's hands. Multilingual-sensitive aspects play a subordinate role, although students' Language Learning Biographies uncovered their own rich multilingual resources, which, however, seem to be dominated by more monolingually shaped beliefs. From an epistemological perspective, students' beliefs at this point predominantly mirrored a "realist worldview": although 
learners are not explicitly perceived as passive recipients of knowledge, students' statements which opt for co-constructive ways of creating knowledge in the classroom are rare. Rather, activities initiated by the teacher to explicitly learn and practice target language competence are favored.

The category-based analyses of students' "Visit Dartmoor National Park" lesson plans (VD I) revealed that all the categories, that is, all the beliefs explicitly expressed by students at the onset of the classes in the questionnaires "My Language Learning Biography" could be detected in the lesson plans. Interestingly, however, some of the beliefs specific students had mentioned in their Language Learning Biographies did not appear in their lesson plans. This turned out to be true for "student orientation" (table 1, category 1), "differentiation" (table 1, category 1.3), "dealing with mistakes (table 1, category 1.4), "contextualization" (table 2, category 5) and "consideration/diagnosis or activation of prior knowledge" (table 2, category 7). This suggests that the level of importance students ascribed to specific quality criteria of EFL teaching and learning is not necessarily reflected in their lesson plans. It might be assumed here that students either lacked the strategies to transform these beliefs into activities described in the lesson plans or that they mentioned these beliefs in their Language Learning Biographies for they perceived them as being socially desirable. The opposite phenomenon could be detected as well: For instance, "variety of methods" (table 1, category 1.1) was mentioned by a total of fourteen students in their Language Learning Biographies, however, the entirety of twenty-three students included features in their lesson plans which reflect this category. Further, these features were incorporated in the lesson plans in a very sophisticated and differentiated manner. This phenomenon might be explained in two ways: Students may have consciously decided not to mention beliefs clustering around this category in their Language Learning Biographies, or specific beliefs were only subconsciously present at the beginning of the classes but, in spite of this, made their way into the lesson plans.

Students' written reflections may help to clarify the case. Here, they elaborated on a possible connection between their Language Learning Biographies and their lesson plans. All the students $(\mathrm{N}=23)$ confirmed such a connection, as illustrated by the statement put forward by $\mathrm{p} 17$ :

"In my lesson plan, I tried to include elements of a vocabulary introductory lesson I personally find important. As mentioned in my Language Learning Biography, this includes giving a context to the vocabulary (gap text about Dartmoor), visual support (icons) and securing the vocabulary through a creative writing task (partner quiz and homework). Therefore, I can confirm that my Language Learning Biography is closely related to the way I conducted the lesson plan" (p17)

The following excerpt (p2) the content of which was repeated in nearly all students' reflections helps to shed light on the phenomena portrayed above. It shows that teaching and learning experiences made by students as former pupils influence lesson planning while at the same time guiding students' decisions in an unconscious way:

"The beginning of the lesson seems to have come to my mind automatically because so many new units in my own school time were introduced using the book. While I was conscious to the fact that such a beginning could be boring, it was hard for me to think of other possible ways to start a lesson that would be both interesting and feasible" (p2)

Interestingly, p2 refers to her identity as a former pupil, or "self-as learner" (Kiss 2012: 22) while simultaneously drawing on her identity as a teacher, or "self-as teacher" (Kiss 2012: 22), the latter of which obviously cannot yet be enacted due to a lack of strategies ("possible ways to start a lesson"). Additionally, a lack of strategies to develop belief-based lesson activities seems to have prevented students to transform these beliefs into lesson planning ("such a beginning could be boring"). More practical considerations seem to have influenced the guiding function of existing beliefs as well: 
"While I first thought about some kind of puzzle or memory, I was not sure about the practicality of those ideas. I was not sure if such tasks would be too easy for the pupils, which is why I stuck to the boring, but at least reliable method of using the introductory pages of the book" (p7)

As for the second research question, the sources of students' beliefs at the beginning of the classes clustered around three major categories:

1) Personal experiences as former pupils in EFL teaching ( $N=23,100 \%)$

2) Students' practical EFL teaching experiences ( $N=16,69.57 \%)$

3) Teacher education classes at a university level and their accompanying activities such as paper writing, exam preparations, or self-study ( $\mathrm{N}=15,62.22 \%)$

As the numbers in brackets indicate, it seems to be the case that personal language learning experiences as former school pupils have shaped present-day beliefs to a considerable extent, as compared to format teacher education classes. Students' practical teaching experiences seem to be a rich source of beliefs as well. Whenever students' elaborations on the sources of their beliefs allowed for it, for example when expressions such as "predominantly", "the most" or "little" had been used, the degree of emphasis students ascribed to specific sources was determined ( $3=$ to a high extent, $2=$ to a medium extent, 1=to a lesser extent). In terms of the influence students' former experiences as pupils had on their present-day beliefs an average degree of emphasis of 2.9 was calculated, followed by students' teaching experiences (2.4) and university classes (2.2). Quite unsurprisingly, and in line with previous research, students' past experiences (category 1 ) seem to have a much more significant impact on their beliefs than more present (category 2) or future-oriented (category 3 ) ones. The implications which go along with this finding in terms of teacher professional trainings are presented in the last section of this paper.

In a next step, subcategories of the three overarching categories were developed. As for the first category, a total of four subcategories was derived from students' data, the definitions of which are accompanied by examples from students' texts for clarification purposes:

1.1) Negatively connotated experiences as former pupils in EFL teaching ("The beliefs about how not to teach are predominantly rooted in my experiences as a former learner" p11)

1.1.1) Negatively connotated experiences as former pupils in EFL teaching which result in pre-service teachers' attempts to design and implement teaching and learning scenarios different from the ones of their former teachers ("Negative experiences which encourage me not to make the same mistakes" p10)

1.2) Positively connotated experiences as former pupils in EFL teaching ("From a pupil perspective you can easily tell whether a specific method works or not" p20)

1.2.1) Positively connotated experiences as former pupils in EFL teaching which result in pre-service teachers' attempts to create and implement teaching and learning scenarios similar to the ones of their former teachers ("I was surprised to see how much I had adopted from my former teachers" p1)

As for the second category, students' practical teaching experiences, three subcategories emerged from students' data:

2.1) Practical teaching experiences led to the development of new perspectives/views ("My own experiences as a teacher primarily led to beliefs about how teachers should act when teaching" p13)

2.2) Practical teaching experiences as a touchstone for the practicality of theoretical knowledge gained at university ("I put theories discussed at university in relation to more practical issues, thereby questioning the theories" $\mathrm{p} 3$ )

2.3) Practical teaching experiences serve to help students reflect on their professional development ("I still make mistakes I would like to avoid in the future" p18)

Finally, three subcategories could be derived from students' elaborations on university teacher education classes as sources of their beliefs: 
3.1) University classes lead to an extension of existing beliefs by adding (theoretical) pedagogic content knowledge ("My initial beliefs were extended by the classes I attended" p22)

3.2) University classes confirm existing beliefs ("The papers I have written so far strengthened my beliefs" p19)

3.3) University classes enable students to explain existing beliefs and experiences retroactively/in a reconstructive manner ("Through my studies, I was finally able to understand what had happened in the classroom" p6)

The number of students who could be assigned to each (sub-)category shows that positively and negatively connotated experiences students had made as former pupils have a similar amount of influence on students' beliefs ( $N=14, N=15)$. In terms of the influence these experiences have, according to students, on their prospective teaching behavior, it is worth mentioning that while eight students underlined that they want to act differently than their former teachers, only one student seems to be willing to adopt former teachers' behavior. Further, it seems that students' own practical teaching experiences lead to the development of beliefs and convictions which, in turn, find their (theoretical) extension in university classes.

The "Visit Dartmoor" lesson plans handed in by students towards the ending of the classes (VD II) served as a touchstone for the development of students' multilingual action competence. All of the lesson plans showed numerous multilingual-sensitive elements. They involved the inclusion of pupils' first languages (L1s) in various forms and for different purposes: As a social form, L1-heterogeneous and L1-homogeneous groups of learners were formed, in the latter of which learners shared the same L1s. Pupils' first languages were also included in different phases of the lessons planned to introduce new vocabulary, to decode the meaning of new words as well as to memorize and use them in meaningful contexts. Further, pupils' L1s served to create multilingual-sensitive teaching and learning material such as worksheets. By considering pupils' L1s students intended to create a classroom atmosphere within which languages and pupils' linguistic resources are valued. What also changed from VD I to VD II lesson plans is the role teachers are to play in the EFL lessons designed. Whereas they were engaged in providing input to learners in a rather transmissive way in VD I, they played various roles in VD II, for instance as learners who made themselves familiar with pupils' languages to purposefully integrated them into teaching and learning processes, as moderators who initiated language comparisons and summarized and further elaborated on pupils' contributions in multilingual discourses and, finally, as language exerts to enhance pupils' target language competence. This change in teacher roles was accompanied by an altered view on pupils who were now (in VD II) seen as language (learning) experts who could actively share their explicit and implicit L1 language knowledge and their prior language learning experiences, especially when they had already learned additional languages before English.

When elaborating on possible connections between their Language Learning Biographies and their VD II lesson plans, many students emphasized that a predominant part of this connection is the fact that they had never experienced multilingual-sensitive teaching and learning as former pupils:

"When I remember my own English lessons at school, there are no multilingual aspects which come to my mind. I think the multilingual approach was not part of my teachers' education" (p2)

The resulting lack of multilingual-sensitive elements in the VD I lesson plans is reflected in the next statement, as well as the relation between gaining new pedagogical content knowledge and lesson planning:

"I would not have created multilingual-sensitive lessons because the English-only-approach accompanied me in all stages of education. Being used to the prevalent 'monolingual habitus', I did not include any multilingual-sensitive elements in the first version of the 'Visit 
Dartmoor' task. When revising it in order to make it multilingual-sensitive, I founded my plan on the knowledge and inspiration gained in class" (p7)

The first part of the above quote suggests that the lack of multilingual-sensitive elements in the first "Visit Dartmoor" lesson plan (VDI) is based on the student's conscious decision not to include them. However, the fact that the "knowledge" and "inspiration" developed throughout the class led this student to design the second "Visit Dartmoor" lesson plan (VDII) in more multilingual-sensitive ways supports the assumption that the task to design a multilingual-sensitive lesson plan posed a challenge, a "disequilibrium" for students at the beginning of the classes.

A number of students indicated that the beliefs they had expressed in their Language Learning Biographies at the beginning of classes had changed:

"It is interesting to see that I - without noticing it directly - tried to put the exact same things into my lesson plan which I wrote in my Language Learning Biography before. But now, after making my lesson plan multilingual-sensitive, I have the feeling that my Language Learning Biography changed [...]. I would now include aspects of [multilingualism] in my view of a good lesson" (p14)

In the questionnaires filled out by students towards the ending of the classes two items aimed to elicit insights about possible changes in students' beliefs: (1) Do you think your beliefs as exemplified in your Language Learning Biography at the onset of the class have changed? If so, in what way(s) and to what extent?", (2) "What do you think are the reasons for this change/these changes?"

The majority of students pointed out that, although their beliefs had not changed in a fundamental way, they were extended for beliefs about the necessity of multilingual-sensitive teaching and learning had been added to their belief system. This kind of change corresponds to the notion of "addition" in earlier research conducted by Cabaroglu and Roberts (2000) who offer a "set of [belief] change process categories" (ibid.: 394). Those students who argued that their beliefs had actually changed stated that beliefs about the appropriateness of an "English-only-approach" had been replaced by beliefs about the meaningfulness of a multilingual-sensitive approach. Other students stressed that parts of their initial beliefs were prioritized and differentiated: Multilingual-sensitive teaching had gained importance, resulting in a more critical view on the exclusive use of the target language in the EFL classroom. These changes may well be classified into Cabaroglu and Robert's categories of "disagreement" and "reordering", the former of which refers to a "rearrangement of beliefs regarding their importance", and the latter of which comprises the "rejection of existing beliefs" (ibid.: 393). A social desirability bias cannot be entirely ruled out here, that is, it may be the case that students indicated a change in beliefs for they might have thought that this is expected by the course instructor, thereby masking what has become known as superficial belief change (Kubanyiova 2012). To reduce the likelihood of such a bias participants were explicitly told that "no change" was a reasonable option to opt for in the final questionnaires as well.

Belief developments were first and foremost ascribed to the discussion of theoretical texts and to new knowledge gained this way, followed by the reflection tasks and the design of the VD lesson plans. This order of priority suggests that teacher education trainings the intention of which is to have an impact on teachers' beliefs should spend a vast amount of effort on the development of new pedagogical content knowledge among teachers and to embed this knowledge into teaching and learning scenarios through collective analyses of teaching videos. Only then teachers should be asked to design lessons for training purposes: This way new beliefs which are in the process of evolving and closely related to the development of new knowledge may not be covered or suppressed by a lack of strategies to implement these beliefs in lesson planning. The ways beliefs developed according to students (extension, change, prioritization and differentiation) mirror Borg's (2006) conceptions of 
changes of the content and the structure of teachers' beliefs. Quite interestingly, students rather ascribed these changes to the development of new pedagogical content knowledge than to "reflectionfor-action" (Farrell 2007), i.e. the design of their lesson plans. Following the epistemological classification of beliefs development exemplified by Schraw et al. (2017b), students' beliefs as reflected in the multilingual-sensitive lesson plans can be defined as being "contextualist". Some may even be perceived as belonging to the "relativist worldview", especially since students emphasized the role of the teacher as that of a "learning facilitator" and the partly autonomous control individual pupils should have of their own learning processes.

\section{Conclusion}

Two pre-service EFL teacher training classes were subject to analysis in the present investigation. The aims of the study were to uncover participants' pre-existing beliefs about quality criterial of EFL teaching and learning (with a lexical focus), and to gain insights into the ways these beliefs developed (or not) throughout the classes within which participants' multilingual action competence was to be developed. It has been shown that participants' initial beliefs clustered around EFL teaching and learning principles which rather mirrored monolingual than multilingual perspectives, a finding which deserves attention given that participants brought rich multilingual resources to classes themselves (for insights into how these resources may support multilingual EFL teaching, see Otwinowska 2017 and Niesen 2017). However, their own first, second and foreign language acquisition and learning experiences did not seem to have entered their belief system about quality criteria of EFL teaching and learning. Another possibility is that they felt reluctant to explicitly refer to these experiences for they perceived them as irrelevant, or, even worse, not valued in the given context. Both assumptions are extensively supported by prior research, first and foremost by a comprehensive study conducted by Ellis (2016). Quite impressively, the author had called for an inclusion of teachers' language learning experiences that is their "experiential knowledge" into any attempt to illuminate their beliefs in an earlier study:

"If experiential knowledge is accepted as a powerful contributor to teachers' beliefs, and if experiential knowledge includes not only that derived from classroom teaching and learning but also from life experience, then language learning experience, formal or informal, must be worthy of investigation in terms of how it influences teachers' store of knowledge and beliefs" (Ellis 2006: 8).

Suggestions as to how teachers' "experiential knowledge" may enter formal professional development classes are outlined towards the ending of this section. Before that, the results of the study at hand shall be further summarized.

Monolingual approaches were also detected in participants "reflection-for-action" processes (Farrell 2007), that is in their "Visit Dartmoor" lesson plans at the beginning of classes (VDI). Throughout classes, students' multilingual action competence was developed so as to enable them to redesign their VDI lessons plans in multilingual-sensitive manners. This task, however, did not turn out to have influenced the development of their beliefs about quality criteria of EFL teaching (with a lexical focus) the most. This effect was rather ascribed to the development of new knowledge gained throughout the analysis and discussion of theoretical texts on multilingual-sensitive teaching, followed by reflections on possible connections between lesson planning and beliefs. It is safe to say at this point that the continuous inclusion of participants' beliefs while developing their multilingual action competence turned out to be a fruitful exchange and indeed seems to be a happy marriage. This finding has direct implications for the design and implementation of pre-service, but also in-service EFL teacher training classes which attempt to pave the way for multilingual-sensitive teaching and learning in real-world school surroundings: It is of vital importance that teachers' pre-existing beliefs about teaching and learning are taken seriously, a point which echoes Cabaroglu and Robert's (2000) call to make these beliefs "as explicit as possible" (ibid.: 399). In the study at hand, these beliefs predominantly clustered around participants' school experiences as former pupils. However, to draw a more holistic picture of their convictions (and the 
roots of these convictions), other surroundings have to be taken into consideration as well: For example, participants' own multilingual resources and the ways these resources have been and are actually used in and outside formal educational institutions should be addressed in any attempt to introduce students to multilingual-sensitive tenets of language teaching and learning, and to foster their multilingualsensitive professional competence. What makes this a real challenge is the fact that existing beliefs are indeed firmly rooted in prior school experiences which were often shaped by monolingual understandings of teaching and learning. Only when multilingual-sensitive teaching becomes the norm rather the exception in EFL classrooms teacher educators can expect future teachers to bring beliefs which reflect multilingual-sensitive teaching approaches to university. Until this is the case, teacher educators face a two-fold challenge, namely to pave the way for multilingual principles to enter teachers' belief systems and to foster their multilingual action competence. The present study has shown that both is possible. However promising the results may be though, they are subject to limitations, at least from a "chaotic systems ontology" (Burns, Freeman \& Edwards 2015) which shall be adopted here: If we accept that teacher learning is "non-linear", shaped by "feedback-loops" and that "the interactions in the sessions, comments, arguments, and input materials can trigger different thought processes" (Kiss 2012: $18,30)$, it will be naïve to conclude from this study that all participants have learned the same things (here: multilingual action competence) in the course of the classes. Rather, it must be conceded that what students have actually learned in the classes portrayed here, and the beliefs about multilingual teaching which have entered their belief systems, will be filtered by their personal understanding of how they perceive themselves as (past) EFL learners, (present) EFL teacher trainees and (future) EFL teachers. Hence, it is questionable whether the participants of this study will be able and willing to use what they have learned in their future teaching, especially when taking into account Kiss's (2012) finding that "a linearly arranged educational experience causes student teachers reject 'theory' in the complex, chaotic, and non-linear reality of classroom teaching" (ibid.: 32). The author adds that "the tension between learning in one system and applying their knowledge in a completely different system prompts many (student) teachers to view their formal teacher education as irrelevant in their everyday practice. Unfortunately, a feasible solution is yet to be offered" (ibid.: 32). The design of university classes which offer pre-service teachers the "freedom and flexibility that does not curtail the natural emergence of teacher learning" (Kiss 2012: 33) is not an easy task, especially since it seems to run counter the diagnosis and assessment of participants' professional development. What aggravates the situation is the fact that although the participants of this study are free to choose from various pre-service EFL teacher training classes offered by the respective institute, a certain compulsion goes with attending a course unit, especially in terms of having to pass the course. Despite these constraints, it is my firm belief that university classes can and should be designed in such a way as to be sensitive to participants' multilingual-sensitive professional development from a "chaotic systems ontology" (Burns et al. 2015), and moreover, to make it more likely for multilingual teaching tenets to enter real-world EFL classrooms: A promising approach to do so is, to my view, the implementation of video-based digital learning platforms in "Enriched Virtual Formats" (Christensen et al. 2012, see also Niesen, forthcoming) which allow pre-and in-service teachers to (re-)visit the learning unit "Multilingual-sensitive action competence" whenever needed in (future) teaching and to engage in "self-regulated learning opportunities" (Cabaroglu \& Roberts 2000: 399). Such a digital format, which ideally includes explanatory as well as teaching videos allows teachers to work through the unit at their own pace and in whatever place that is most comfortable for them. Reflection tasks in this digital format could capture teachers' past, present, and evolving beliefs, and they could further allow teachers to connect these beliefs to past, present, and intended teaching and learning practices. Moreover, reflection tasks could make teachers' aware of their own formal and informal language learning experiences, their "experiential knowledge" to raise their awareness as to how this knowledge shapes their beliefs about teaching and learning. In the best case, the virtual learning format offers pre- and in-service teachers a forum within 
which they can share and cooperatively develop these beliefs, their own multilingual resources as well as their experiences when employing multilingual teaching in their classrooms, to make, in the long run, the wedding of multilingual-sensitive action competence and teacher beliefs not only a happy, but a lasting marriage.

\section{References}

Archer, P. A. (2007). Making our Way through the World: Human Reflexivity and Social Mobility. Cambridge, UK: Cambridge University Press.

Ashton, P. T. (2015). Historical overview and theoretical perspectives of research on teachers' beliefs, in: H. Fives, M. G. Gill, International Handbook of Research on Teachers' Beliefs, New York and London: Routledge, 31-47.

Baumert, J. \& Kunter, M. (2006). Stichwort: Professionelle Kompetenz von Lehrkräften. Zeitschrift für Erziehungswissenschaft, 9 (4), 469-520.

Bialystok, E. (2001). Metalinguistic aspects of bilingual processing. Annual Review of Applied Linguistics, 21, 169181.

Biederstädt, W. (Hg.) (2013). Headlight 2. Berlin: Cornelsen.

Borg, S. (2006). Teacher Cognition and Language Education. Research and Practice. London: Continuum.

Bredthauer, S. \& Engfer, H. (2016). Multilingualism is great - but is it really my business? - Teachers' approaches to multilingual didactics in Austria and Germany. Sustainable Multilingualism, 9, 104-120.

Brownlee, J. L. \& Schraw, G. (2017). Reflection and reflexivity: A focus on higher order thinking in teachers' personal epistemologies, in: G. Schraw, J. L. Brownlee, L. Olafson, M. Vanderveldt, Teachers' Personal Epistemologies. Evolving Models for informing Practice, Charlotte, NC: IAP Publishing, 409-427.

Bündgens-Kosten, J., Elsner, D. \& Hardy, I. (2016). Videoanalyse ein- und mehrsprachiger Lerner/innen bei der computerbasierten Textarbeit: Die Rolle von Code-Switching und Negotiation im frühen Englischunterricht, in: U. Rauin, T. Engartner, M. Herrle, Videoanalysen in der Unterrichtsforschung: Methodische Vorgehensweisen und aktuelle Anwendungsbeispiele, Weinheim \& München: Beltz Juventa, 225-241.

Burns, A., Freeman, D. \& Edwards, E. (2015). Theorizing and studying the language-teaching mind: Mapping research on language teacher cognition. The Modern Language Journal, 99 (3), 585-601.

Butler, Y. G. (2013). Bilingualism/multilingualism and second-language acquisition, in: T. K. Bhatia, W. C. Ritchie, The handbook of bilingualism and multilingualism. $2^{\text {nd }}$ ed. Chichester, UK: Blackwell, 109-136.

Butzkamm, W. (2003). We only learn language once. The role of the mother tongue in FL classrooms: death of a dogma. Language Learning Journal, 28 (1), 29-39.

Cabaroglu, N. \& Roberts, J. (2000). Development in student teachers' pre-existing beliefs during a 1-year PGCE programme. System, 28, 387-402.

Cenoz, J. \& Gorter, D. (2011). A holistic approach to multilingual education: Introduction. The Modern Language Journal, 95 (3), 339-343.

Cenoz, J. \& Gorter, D. (2015). Multilingual Education. Between Language Learning and Translanguaging. Cambridge, UK: Cambridge University Press.

Christensen, C. M., Horn, M. B. \& Staker, H. (2012). Is K-12 Blended Learning Disruptive? An Introduction to the Theory of Hybrids. Clayton Christensen Institute for Disruptive Innovation. https://www.christenseninstitute.org/wpcontent/uploads/2014/06/Is-K-12-blended-learning-disruptive.pdf._ (4 November 2019).

Conteh, J. \& Meier, G. (Eds.). (2014). The Multilingual Turn in Languages Education. Opportunities and Challenges. Bristol: Multilingual Matters.

Cook, V. (2009). Questioning traditional assumptions of language teaching. Nouveaux cahiers de linguistique française, 29, 7-22.

Council of Europe (2001). Common European Framework of Reference for Languages: Learning, Teaching, Assessment. Cambridge, UK: Cambridge University Press. https://rm.coe.int/16802fc1bf (2 November 2019).

Cummins, J. (2007). Rethinking monolingual instructional strategies in multilingual classrooms. Canadian Journal of Applied Linguistics, 10 (2), 221-240.

Cummins, J. (2008). BICS and CALP: Empirical and theoretical status of the distinction, in: B. Street, N. H. Hornberger, Encyclopedia of Language and Education, 2nd ed., vol. 2. New York: Springer, 71-83. 
Cutrim Schmid, E. \& Schmidt, T. (2017). Migration-based multilingualism in the English as a Foreign Language Classroom: Learners' and teachers' perspectives. Zeitschrift für Fremdsprachenforschung, 28 (1), $29-52$. https://www.dgff.de/assets/Uploads/ausgaben-zff/ZFF-1-2017-Cutrim-Schmid-Schmidt.pdf (2 Nov, 2019).

De Angelis, G. (2011). Teachers' beliefs about the role of prior language knowledge in learning and how these influence teaching practices. International Journal of Multilingualism, 8 (3), 216-234.

Dooly, M. (2005). How aware are they? Research into teachers' attitudes about linguistic diversity. Language Awareness, 14 (2-3), 97-111.

Elsner, D. (2015). Inklusion von Herkunftssprachen - Mehrsprachigkeit als Herausforderung und Chance, in: C. M. Bongartz, A. Rohde, Inklusion im Englischunterricht, Frankfurt am Main: Peter Lang, 71-94.

Ellis, E. M. (2006). Language learning experience as a contributor to ESOL teacher cognition. TESL-EJ, 10 (1), 120.https://www.researchgate.net/publication/254476290_Language_Learning_Experience_as_a_Contributor_to ESOL_Teacher_Cognition (20 October 2019).

Ellis, E. (2016). The Plurilingual TESOL Teacher. The hidden Languaged Lives of TESOL Teachers and why they matter. Boston: De Gruyter.

Farrell, Thomas S. C. (2007). Reflective Language Teaching. From Research to Practice. London: Continuum.

Fives, H. \& Buehl, M. M. (2017). The functions of beliefs: Teachers' personal epistemology on the pinning block, in: G. Schraw, J. L. Brownlee, L. Olafson, M. Vanderveldt, Teachers' Personal Epistemologies. Evolving Models for Informing Practice, Charlotte, NC: IAP Publishing, 25-54.

Franceschini, R. (2011). Multilingualism and multicompetence: A conceptual view. The Modern Language Journal, 95 (3), 344-355.

Freeman, D. (2002). The hidden side of the work: Teacher knowledge and learning to teach. A perspective from North American educational research on teacher education in English language teaching. Language Teaching, 35 (1), 1-13.

García, O. \& Wei, L. (2014). Translanguaging. Language, Bilingualism and Education. Basingstoke, UK: Palgrave Macmillan.

Gibbons, P. (2006). Unterrichtsgespräche und das Erlernen neuer Register in der Zweitsprache, in: P. Mecheril, T. Quehl, Die Macht der Sprachen. Englische Perspektiven auf die mehrsprachige Schule. Münster: Waxmann, 269290.

Göbel, K., Vieluf, S., Hesse, H.-G. (2010). Die Sprachtransferunterstützung im Deutsch- und Englischunterricht bei Schülerinnen und Schülern unterschiedlicher Sprachlernerfahrungen. Zeitschrift für Pädagogik, 55, $101-122$.

Gogolin, I. (2008). Der monolinguale Habitus der multilingualen Schule. 2. Aufl. Münster: Waxmann.

González, N, Moll, L., Amanti, C. (Eds.). (2005). Funds of Knowledge: Theorising Practices in Households, Communities and Classrooms. New York: Routledge.

Herdina, P. \& Jessner, U. (2002). A Dynamic Model of Multilingualism. Perspectives of Change in Psycholinguistics. Clevedon: Multilingual Matters.

House, J. (2003). English as a lingua franca: A threat to multilingualism? Journal of Sociolinguistics, 7 (4), $556-578$. $\mathrm{Hu}$, A. (2003). Schulischer Fremdsprachenunterricht und migrationsbedingte Mehrsprachigkeit. Tübingen: Narr.

Jakisch, J. (2014). Lehrerperspektiven auf Englischunterricht und Mehrsprachigkeit. Zeitschrift für Interkulturellen Fremdsprachenunterricht, 19 (1), 202-215.

Jessner, U. (2006). Linguistic Awareness in Multilinguals. English as a Third Language. Edinburgh: Edinburgh University Press.

Johnson, K. E. (2015). Reclaiming the relevance of L2 teacher education. The Modern Language Journal, 99 (3), $515-$ 528.

Kiss, T. (2012). The complexity of teacher learning: Reflection as a complex dynamic system. Journal of Interdisciplinary Research in Education, 2 (1), 17-35.

Kubanyiova, M. (2012). Teacher Development in Action. Understanding Language Teachers' Conceptual Chance. Basingstoke, UK: Palgrave Macmillan.

Kubanyiova, M. \& Feryok, A. (2015). Language teacher cognition in applied linguistics research: Revisiting the territory, redrawing the boundaries, reclaiming the relevance. The Modern Language Journal, 99, 435-449.

Kuckartz, U. (2016). Qualitative Inhaltsanalyse. Methoden, Praxis, Computerunterstützung. 3. Aufl. Weinheim \& Basel: Beltz Juventa.

Lortie, D. C. (1975). Schoolteacher: A sociological study. Chicago: University of Chicago Press. 
May, S. (2014). The Multilingual Turn. Implications for SLA, TESOL and Bilingual Education. New York and London: Routledge.

Meißner, F.-J. (2004). Transfer und Transferieren. Anleitungen zum Interkomprehensionsunterricht, in: H. G. Klein, D. Rutke, Neuere Forschungen zur europäischen Interkomprehension. Aachen: Shaker, 39-66.

Niesen, H. (2017). The development of multilingual EFL teachers' professional vision and practical teaching capabilities in video-based surroundings - do language learning biographies have an impact? Orbis Scholae, 11 (3), 63-84. https://www.cupress.cuni.cz/ink2 stat/dload.jsp?prezMat=116876 (5 November 2019).

Niesen, H. (2018a). The use of teacher trainees' own and peer videos for the introduction of multilingual-sensitive teaching approaches in pre-service teacher training classes, in: J. Buendgens-Kosten, D. Elsner, Multilingual Computer Assisted Language Learning. Bristol: Multilingual Matters, 233-251.

Niesen, H. (2018b). Förderung mehrsprachigkeitssensibler professioneller Handlungskompetenz angehender Englischlehrkräfte. Zeitschrift für Interkulturellen Fremdsprachenunterricht, 23 (1), 121-134.

Niesen, H. (2018c). Mehrsprachige Schüler*innen, mehrsprachige Lehrer*innen? Zur Notwendigkeit des strukturellen Einbezugs der sprachlichen Ressourcen angehender Fremdsprachenlehrkräfte in der Lehrer*innenbildung, in: C. Caruso, J. Hofmann, A. Rohde, K. Schick, Sprache im Unterricht. Ansätze, Konzepte, Methoden. Trier: WVT, 421-438.

Niesen, H. (2019). Zur videogestützten Entwicklung mehrsprachigkeitssensitiver professioneller Wahrnehmungsund Handlungskompetenz angehender Englischlehrkräfte, in: K. Müller, U. B. Müller, I. Kleinbub, Individuelles und gemeinsames schulisches Lernen. Forschungsbeiträge zur Unter-richtsgestaltung und Lehrerbildung bei heterogenen Lernvoraussetzungen. Weinheim und Basel: Beltz Juventa, 136-151.

Niesen, H. (forthcoming). Förderung mehrsprachigkeitssensitiver, professioneller Wahrnehmungs- und Handlungskompetenz angehender Englischlehrkräfte in digitalen, videogestützten Lernumgebungen, in: D. Elsner, H. Niesen, B. Viebrock, Hochschullehre digital gestalten in der (fremd-)sprachlichen Lehrerlnnenbildung - Inhalte, Methoden und Aufgaben. Tübingen: Narr.

Ortega, L. (2014). Ways forward for a bi/multilingual turn in SLA, in: S. May, The Multilingual Turn. Implications for SLA, TESOL and Bilingual Education, New York and London: Routledge, 32-53.

Oser, F. \& Blömeke, S. (2012). Überzeugungen von Lehrkräften. Einführung in den Thementeil. Zeitschrift für Pädagogik, 58 (4), 415-421.

Otwinowska, A. \& De Angelis, G. (Eds). (2014). Teaching and Learning in Multilingual Contexts. Sociolinguistic and Educational Perspectives. Bristol: Multilingual Matters.

Otwinowska, A. (2017). English teachers' language awareness: Away with the monolingual bias? Language Awareness, 16 (4), 304-324.

Otwinowska, A. (2016). Cognate Vocabulary in Language Acquisition and Use. Attitudes, Awareness, Activation. Bristol: Multilingual Matters.

Parkinson, M. \& Maggioni, L. (2017). The potential of course interventions to change preservice teachers' epistemological beliefs, in: G. Schraw, J. L. Brownlee, L. Olafson, M. Vanderveldt, Teachers' Personal Epistemologies. Evolving Models for informing Practice, Charlotte, NC: IAP Publishing, 215-237.

Reissner, C. (2019). Englisch als europäische Brückensprache, in: C. Fäcke, F.-J. Meißner, Handbuch Mehrsprachigkeits- und Mehrkulturalitätsdidaktik, Tübingen: Narr, 455-458.

Reusser, K. \& Pauli, C. (2014). Berufsbezogene Überzeugungen von Lehrerinnen und Lehrern, in: E. Terhart, H. Bennewitz, M. Rothland, Handbuch der Forschung zum Lehrerberuf, 2. Aufl. Münster: Waxmann, 642-661.

Schmelter, L. (2005). Fehler und Korrekturen als Grenzüberschreitungen. Korrekturerwartungen und Korrekturkriterien beim Fremdsprachenlernen im Tandem, in: S. Duxa, Grenzen überschreiten: Menschen, Sprachen, Kulturen. Festschrift für Inge Schwerdtfeger zum 60. Geburtstag. Tübingen: Narr, 315-324.

Schnuch, J. (2015). Inklusion und Mehrsprachigkeit: Die Rolle von Sprachbewusstheit im plurilingualen Spracherwerb, in: C. M. Bongartz, A. Rohde, Inklusion im Englischunterricht, Frankfurt am Main: Peter Lang, 117143.

Schraw, G., Olafson, L. \& Lunn, J. (2017a). Teachers' personal epistemologies. Theoretical and practical considerations, in: G. Schraw, J. L. Brownlee, L. Olafson, M. Vanderveldt, Teachers' Personal Epistemologies. Evolving Models for informing Practice, Charlotte, NC: IAP Publishing, 3-21.

Schraw, G., Olafson, L. \& Vander Veldt Brye, M. (2017b). Teaching knowledge and beliefs in preservice teachers, in: G. Schraw, J. L. Brownlee, L. Olafson, M. Vanderveldt, Teachers' personal epistemologies. Evolving models for informing practice, Charlotte, NC: IAP Publishing, 323-349. 
Shulman, L. S. (1986). Those who understand: Knowledge growth in teaching. Educational Researcher, 15 (2), 4-14. Tschannen-Moran, M., Salloun, S. J. \& Goddard, R. D. (2017). Context matters. The influence of collective beliefs and shared norms, in: G. Schraw, J. L. Brownlee, L. Olafson, M. Vanderveldt, Teachers' Personal Epistemologies. Evolving Models for informing Practice, Charlotte, NC: IAP Publishing, 301-316.

Tsui, A. B. M. (2012). The dialectics of theory and practice in teacher knowledge development, in: J. Hüttner, B. Mehlmauer-Larcher, S. Reichl \& B. Schiftner, Theory and Practice in EFL Teacher Education. Bridging the Gap, Bristol: Multilingual Matters, 16-37.

Vetter, E. \& Jessner, U. (Eds.). (2019). International Research on Multilingualism: Breaking with the Monolingual Perspective. Cham: Springer Nature Switzerland.

Weinert, Franz E. (2001). Concept of competence: A conceptual clarification, in: D. S. Rychen, L. Salganik, Defining and Selecting Key Competencies, Seattle: Hogrefe \& Huber Publishers, 45-65. 